\title{
PERFORMA BABI BALI YANG DIPELIHARA DALAM KANDANG LANTAI BAPUK DAN BETON
}

\author{
BUDAARSA, K., A. W. PUGER, T. I. PUTRI, I D. G. A. UDAYANA DAN I.W. SUDIASTRA \\ Fakultas Peternakan Universitas Udayana \\ e-mail: bdr.komang@unud.ac.id
}

\begin{abstract}
ABSTRAK
Penelitian ini bertujuan untuk mengetahui performa babi bali antara yang dipelihara dalam kandang lantai bapuk (deep litter) dengan lantai beton. Masing-masing kelompok terdiri dari 10 ekor babi bali dengan berat 10-12 kg. Pakan yang diberikan sama untuk kedua kelompok. Data dianalisis dan diuji dengan Two Independent Sample T test. Variabel yang diukur adalah konsumsi pakan, pertambahan bobot, konversi pakan dan kecernaan ransum. Hasil penelitian menunjukkan bahwa pertambahan bobot badan harian pada kandang bapuk dibandingkan dengan kandang lantai beton $0,3540 \pm 0,0084$ vs $0,3680 \pm 0,0103 \mathrm{~kg}(\mathrm{P}<0,05)$, konversi pakan 3,2106 $\pm 0,0796$ vs 3,1108 $\pm 0,0895(\mathrm{P}<0,05)$, konsumsi pakan harian 1,1360 \pm 0.0117 vs 1,1440 $\pm 0,0117 \mathrm{~kg}(\mathrm{P}>0,05)$. Kecernaan bahan kering 79,1840 $\pm 0,5700$ vs $82,0800 \pm 1,2518 \%$, bahan organik $80,6620 \pm 0,7633$ vs $82,5340 \pm 0,5046 \%$, protein kasar $81,5730 \pm 0,8219$ vs $83,7310 \pm 1,6578 \%$, serat kasar $81,5730 \pm 0,8219$ vs $83,7310 \pm 1,6578 \%$, lemak kasar 87,6820 $\pm 0,8633$ vs 89,1800 $\pm 0,8202 \%$ dan energi $80,7200 \pm 1,0696$ vs $81,0620 \pm 1,0892 \%$ dan semua variabel kecernaan pada kandang beton nyata lebih tinggi $(\mathrm{P}<0,05)$. Dapat disimpulkan bahwa pemeliharaan babi lokal (babi bali) dengan kandang beton menunjukkan performa yang lebih baik ditinjau dari aspek pertambahan bobot, konversi pakan dan kecernaan ransum.
\end{abstract}

Kata kunci: babi bali, performa, bapuk, beton

\section{PERFORMANCE OF BALI PIGS RAISED IN BAPUK AND CONCRETE FLOOR}

\begin{abstract}
This study aims to determine the performance of balimpig by comparing the pig raised in the the bapuk (deep litter) and concrete floor. Each group consists of 10 bali pigs weighing 10-12 kg. The feed given is the same for both groups. Data were analyzed and tested Two Independent Sample T test. The variables measured were feed consumption, weight gain, feed conversion and feed digestibility. The results showed that the average daily weight gain on the bapuk compared with concrete floor were $0.3540 \pm 0.0084 \mathrm{vs} 0.3680 \pm 0.0103 \mathrm{~kg}(\mathrm{P}<0.05)$, feed conversion $3.2106 \pm 0.0796$ vs $3.1108 \pm 0.0895(\mathrm{P}<0.05)$, daily feed intake $1.1360 \pm 0.0117$ vs $1.1440 \pm 0.0117$ $(\mathrm{P}>0.05)$. Dry matter digestibility $79.1840 \pm 0.5700$ vs $82.0800 \pm 1.2518$, organic matter $80.6620 \pm 0.7633$ vs $82.5340 \pm 0.5046$, crude protein $81.5730 \pm 0.8219$ vs $83.7310 \pm 1.6578$, crude fiber $81.5730 \pm 0.8219$ vs $83.7310 \pm$ 1.6578 , crude fat $87.6820 \pm 0.8633 \mathrm{vs} 89.1800 \pm 0.8202$ and energy $80.7200 \pm 1.0696 \mathrm{vs} 81.0620 \pm 1.0892$ and all digestibility variables in the concrete floor were significantly higher $(\mathrm{P}<0.05)$. It can be concluded that the native pig (bali pig) raised in the concrete floor shows better performance in terms of weight gain, feed conversion and feed digestibility.
\end{abstract}

Keyword: performance, bali pig, performance, bapuk, concrete

\section{PENDAHULUAN}

Babi bali merupakan plasma nutfah populasinya terus menurun. Data Badan Statistik Provinsi Bali tahun 2015 menunjukkan bahwa populasinya turun dari 272.528 ekor pada tahun 2012, menjadi 215.321 ekor pada tahun 2015, mengalami penurunan 20.97. Babi bali masih dipelihara secara tradisional, tidak dikandangkan, pakan seadanya tanpa ada perhatian terhadap kuantitas dan kualitas sehingga mutunya menjadi rendah. Pemeliharaan babi bali secara tradisional ini oleh masyarakat di Bali disebut dengan istilah "tatakan banyu". Artinya, babi yang dipelihara hanya sekedar penampung "banyu", yaitu segala limbah yang dihasilkan selama proses memasak di dapur. Babi dipelihara umumnya diikat dengan tali di bawah pohon pada tegalan supaya teduh, dan tidak dibuatkan kandang secara khusus. Dalam keadaan demikian maka 
babi akan kehujanan pada saat musim hujan. Bahkan berkubang dalam lumpur yang bercampur dengan kotoran dan kencingnya sendiri. Salah satu kendala beternak babi adalah bau kotoran yang menyengat dan sering mengundang lalat yang banyak.

Pemeliharaan babi bali dengan cara intensif dan permanen dengan alas beton dengan manajemen yang baik, mulai dari perkandangan, makanan serta perawatannya memang mampu meningkatkan produksi (Budaarsa, et al., 2016), tetapi bagi peternak kecil yang kurang mampu tidak bisa menerapkannya. Oleh karena itu perlu dibentuk sebuah sistem pemeliharaan yang lebih sederhana sehingga memungkin diterapkan oleh peternak kecil di pedesaan. Selain itu peternakan babi sering mendapat keluhan karena baunya yang menyengat dan mengundang banyak lalat. Floresa (2014) melaporkan bahwa salah satu cara beternak babi yang murah dan mampu mengurangi bau, serta lalat adalah dengan memberi alas berbahan organik pada kandangnya. Pemeliharaan babi dengan sistem bapuk adalah pemeliharaan babi yang alas kandangnya terbuat dari litter (alas kandang) yang terdiri dari sekam padi, serbuk gergaji serta jerami yang diberi EM4, yang nantinya sekaligus menjadi pupuk. Pemeliharaan babi dengan sistem bapuk selain, lebih murah juga bisa mengurangi bau kotoran, dan mengurangi lalat. Kondisi kandang yang lebih baik akan memberikan kontribusi terhadap kesehatan ternak dan pada akhirnya terhadap kemampuan mencerna pakan dan memberikan pertumbuhan yang sehat.

Berdasarkan hal terebut maka penelitian ini adalah untuk mengetahui performa babi bali yang dipelihara dengan sistem bapuk dan alas beton.

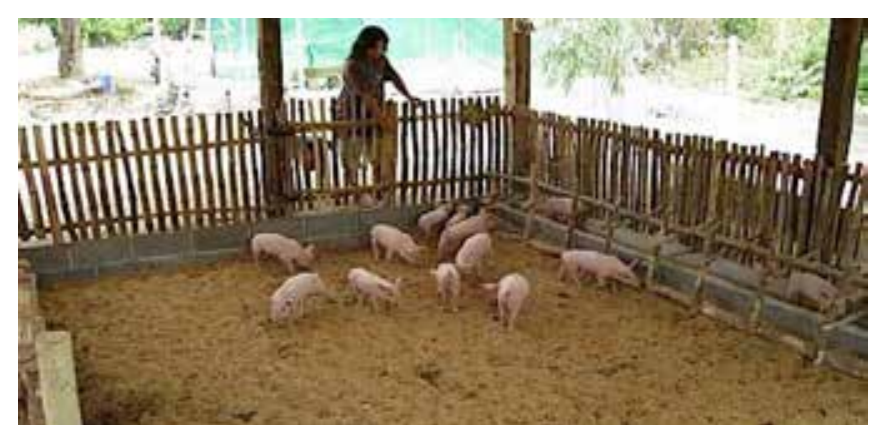

Gambar 1 Kandang babi menggunakan bahan-bahan organik (dikuti dari Folesa, 2014)

\section{MATERI DAN METODE}

\section{Kandang}

Penelitian ini menggunakan dua jenis kandang yaitu kandang alas beton dan kandang bapuk. Kandang bapuk dibuat secara tradisional dengan alas litter dari sekam, serbuk gergaji dan jerami dengan perbandingan
1:1:1 (volume). Lantai berukuran $3 \times 5 \mathrm{~m}$, digali sedalam 90-100 cm, kemudian campuran sekam, serbuk gergaji, jerami dan tanah ditimbun ke dalam lubang tadi.

\section{Ternak}

Ternak yang digunakan dalam penelitian ini adalah babi bali yang sudah disapih, dengan berat badan ratarata 10-12 kg. Penelitian dilaksanakan selama 4 bulan. Sebelum diberi perlakuan, babi diberikan vaksin SE dan obat cacing.

\section{Ransum}

Pakan yang diberikan adalah kombinasi antara konsentrat, jagung, polar dan mineral. Pakan yang diberikan kepada kedua kelompok adalah sama.

\section{Metode}

Metode yang digunakan dalam penelitian adalah metode riset dengan membandingkan babi bali dipelihara dengan sistem bapuk dengan babi bali yang dipelihara dengan kandang berlantai beton. Masingmasing kelompok terdiri atas babi bali sebanyak 10 ekor dengan berat antara 10-12 kg.

Tabel 1. Susunan serta kandungan energi dan protein ransum percobaan

\begin{tabular}{lc}
\hline \multicolumn{1}{c}{ Susunan Ransum } & Komposisi \\
Jagungkuning(\%) & 40 \\
Polar(\%) & 41 \\
Konsentrat (\%) & 18 \\
Mineral (\%) & 1 \\
Jumlah & 100 \\
Kandungan Nutrisi & \\
ME (kkal/kg) & 2805 \\
PK & 16,08 \\
Ca & 0,61 \\
P & 0,71 \\
SK & 7,59 \\
\hline
\end{tabular}

Keterangan: Sampai saat ini belum ada standar kebutuhan nutrisi untuk babi bali

\section{Peubah yang Diukur}

1. Konsumsi pakan harian, Pertambahan Bobot Badan harian dan feed convertion ratio (FCR).

2. Kecernaan ransum meliputi: koefisien cerna bahan kering (KcBK), koefisien cerna bahan organik, koefisien cerna protein kasar, koefisien cerna serat kasar, koefisien cerna lemak kasar, dan koefisien cerna energi

\section{Analisis Data}

Untuk melihat perbedaan peubah yang diamati antara babi bali yang dipelihara dengan sistem bapuk dengan kandang berlantai beton maka data hasil penelitian diolah dengan menggunakan $\mathrm{Uji}_{\mathrm{t}}$ (t-test) menurut Steel dan Torrie (1991). 


\section{HASIL DAN PEMBAHASAN}

Pertambahan bobot badan harian babi bali yang dipelihara dalam kandang alas bapuk lebih rendah $(\mathrm{P}<0,05)$ dibandingkan dengan alas beton yaitu 0,3540 $\pm 0,0084$ vs $0,3680 \pm 0,0103 \mathrm{~kg} /$ hari. Konsumsi pakan babi bali yang dipelihara dalam kandang alas bapuk cenderung lebih rendah $(\mathrm{P}>0,05)$ dibandingkan dengan alas beton yaitu $1,1360 \pm 0,0117$ vs $1,1440 \pm 0,0117 \mathrm{~kg} /$ hari. Konversi pakan pakan babi bali yang dipelihara dalam kandang alas bapuk lebih rendah $(\mathrm{P}<0,05)$ dibandingkan dengan alas beton yaitu 3,2106 $\pm 0,0796$ vs 3,1108 $\pm 0,0895$. Pertambahan bobot badan rata-rata untuk babi bali dipelihara dalam kandang bapuk adalah o,3540 kg sedangkan untuk kandang beton $0,3680 \mathrm{~kg}$. Lebih tingginya pertambahan bobot badan babi bali di kandang beton diduga karena kondisi kandang beton lebih sejuk karena disiram rutin waktu pembersihan kandang sehingga selera makan babi di kandang beton cenderung lebih tinggi. Kecenderungan pakan dimakan lebih tinggi menyebabkan bobot badan lebih tinggi dan ini ditunjang oleh konversi pakan pada kandang beton lebih baik. Hal ini ditunjang oleh pendapat Correa et al. (2000) bahwa pemeliharaan babi dengan lantai deep litter pada daerah panas atau cuaca lebih panas mungkin menyebabkan proses composting pada litter lebih cepat sehingga memberikan pengaruh negatif terhadap pertumbuhan babi.

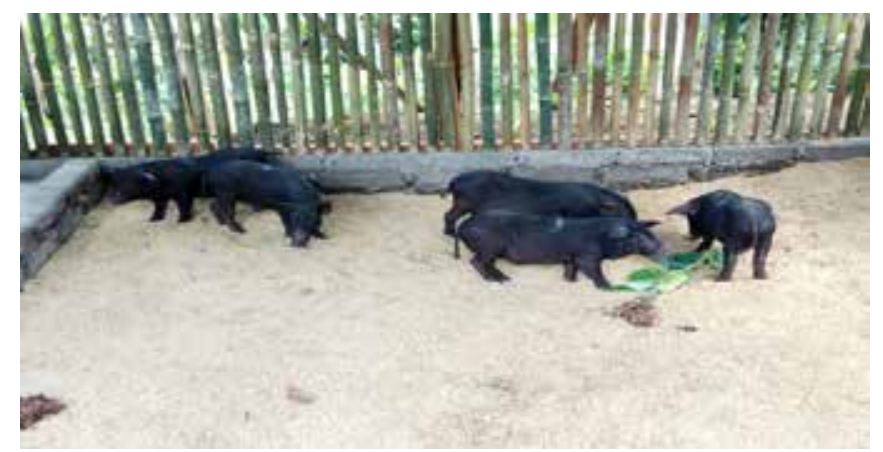

Gambar 2. Babi di kandang Bapuk

Hasil yang berbeda ditunjukkan oleh Correa et al. (2009) mengadakan penelitian di Brazil dan mendapatkan bahwa tidak terdapat perbedaan performa pertumbuhan babi penggemukan yang dipelihara dengan lantai padat atau beton dibandingkan dengan lantai litter dengan kedalaman $0,5 \mathrm{~m}$ atau $0,25 \mathrm{~m}$, meskipun didapatkan bahwa suhu lantai beton jauh lebih dingin. Lebih lanjut dikatakan suhu pada permukaan lantai beton $18^{\circ} \mathrm{C}$, sedangkan pada deep litter dengan kedalaman $0,5 \mathrm{~m}$ adalah $26,1^{\circ} \mathrm{C}$ dan pada lantai deep litter kedalaman $0,25 \mathrm{~m}$ adalah $24,5{ }^{\circ} \mathrm{C}$. Perbedaan ini mungkin disebabkan babi yang dipelihara di Brazil dipelihara di daerah sedang atau dingin. Demikian juga hasil penelitian Ariana (2011) yang menyatakan bahwa pemeliharaan anak babi dengan model lantai sekam dan model panggung menghasilkan penampilan produksi yang lebih baik jika dibandingkan dengan anak babi yang dipelihara pada model lantai beton. Perbedaan ini diduga karena materi yang dipakai adalah anak babi lepas sapih, dimana suhu lingkungan menjadi hal sangat kritis untuk perkembangan anak babi.

Tabel 2. Performa babi bali yang dipelihara pada kandang bapuk dan kandang alas beton

\begin{tabular}{|c|c|c|c|c|}
\hline Variabel & Kandang Bapuk & $\begin{array}{l}\text { Kandang Alas } \\
\text { Beton }\end{array}$ & & $\begin{array}{l}\text { Signifi- } \\
\text { kansi }\end{array}$ \\
\hline $\begin{array}{l}\text { Pertambahan Berat } \\
\text { badan harian (kg/hari) }\end{array}$ & $0.3540 \pm 0.0084$ & $0.3680 \pm 0.0103$ & $*$ & 0.0009 \\
\hline $\begin{array}{l}\text { Konsumsi Pakan } \\
\text { (kg/hari) }\end{array}$ & $1.1360 \pm 0.0117$ & $1.1440 \pm 0.0117$ & ns & 0.0012 \\
\hline Konversi pakan & $3.2106 \pm 0.0796$ & $3.1108 \pm 0.0895$ & $*$ & 0.0085 \\
\hline $\begin{array}{l}\text { Kecernaan bahan } \\
\text { Kering (\%) }\end{array}$ & $79.1840 \pm 0.5700$ & $82.0800 \pm 1.2518$ & $*$ & 0.0973 \\
\hline $\begin{array}{l}\text { Kecernaan Bahan } \\
\text { Organik (\%) }\end{array}$ & $80.6620 \pm 0.7633$ & $82.5340 \pm 0.5046$ & $*$ & 0.0647 \\
\hline $\begin{array}{l}\text { Kecernaan Protein } \\
\text { Kasar (\%) }\end{array}$ & $81.5730 \pm 0.8219$ & $83.7310 \pm 1.6578$ & $*$ & 0.1308 \\
\hline $\begin{array}{l}\text { Kecernaan Serat } \\
\text { Kasar (\%) }\end{array}$ & $55.0910 \pm 1.3449$ & $56.4270 \pm 1.3373$ & $*$ & 0.1341 \\
\hline $\begin{array}{l}\text { Kecernaan Lemak } \\
\text { Kasar (\%) }\end{array}$ & $87.6820 \pm 0.8633$ & $89.1800 \pm 0.8202$ & $*$ & 0.0842 \\
\hline Kecernaan Energi (\%) & $80.7200 \pm 1.0696$ & $81.0620 \pm 1.0892$ & $*$ & 0.1079 \\
\hline
\end{tabular}

* Nyata berbeda pada taraf $5 \%(P<0,05)$

Kecernaan bahan kering babi yang dipelihara pada lantai bapuk lebih rendah dibandingkan dengan babi dipelihara pada lantai beton yaitu 79,1840 $\pm 0,5700$ vs $82,0800 \pm 1,2518 \%$. Kecernaan bahan organik babi yang dipelihara pada lantai bapuk lebih rendah dibandingkan dengan babi dipelihara pada lantai beton yaitu $80,6620 \pm 0,7633$ vs $82,5340 \pm 0,5046 \%$, diiukuti keadaan yang sama pada kecernaan protein kasar, serat kasar, lemak kasar dan energi. Kecernaan bahan kering dan bahan organik dalam pakan lebih tinggi pada lantai beton menyebabkab kecernaan protein, serat kasar, lemak kasar dan energi juga menjadi lebih tinggi. Lebih tinggi kecernaan pada lantai beton diduga akibat kondisi lingkungan pada lantai beton lebih sejuk, penelitian dilakukan di daerah panas dan kebersihan kandang sangat dijaga sehingga faktor lingkungan sangat mendukung kondisi ternak sehingga dengan diberikan pakan yang sama menyebabkan kecernaannya lebih tinggi.

Pertumbuhan ternak lebih tinggi pada lantai beton yang didukung oleh konversi pakan lebih baik dan kecernaan lebih baik, tetapi pembiayaannya juga menjadi lebih tinggi perlu menjadi catatan dalam usaha beternak babi khususnya bagi peternak kurang mampu dan di daerah kesulitan air. Penggunaan 
limbah pertanian sebagai bapuk menjadi solusi pemecahan limbah pertanian suatu wilayah. Bahan bahan limbah yang dihasilkan di wilayah tersebut menjadi termanfaatkan sehingga dapat menjadi pupuk karena lebih cepat mengalami degradasi. Konsekuensi penggunaan lantai bapuk, harga pembuatan kandang menjadi lebih murah, memperbaiki animal welfare, mengeliminir masalah lingkungan, khususnya bau kandang sangat minimal (tidak menyengat). Pada kandang sistem bapuk, lebih irit menggunakan air, karena kandang tidak perlu dibersihkan setiap hari, sehingga cocok diterapkan pada daerah kering.

\section{SIMPULAN}

Pemeliharaan babi bali dengan kandang beton menunjukkan performa yang lebih baik dibandingkan dengan pemeliharaan lantai bapuk ditinjau dari aspek pertambahan bobot badan, konversi pakan dan kecernaan ransum. Namun kandang dengan sistem bapuk baunya tidak menyengat, serta lebih hemat air, karena tidak perlu membersihkan kandang setiap hari.

\section{UCAPAN TERIMA KASIH}

Terimakasih kami sampaikan kepada Rektor Universitas Udayana atas dana bantuan penelitian melalui dana grup riset sehingga penelitian ini dapat berlangsung.

\section{DAFTAR PUSTAKA}

Ariana I N. T. 2011. Pengaruh Model Lantai Kandang dan Jenis Kelamin terhadap Penampilan Produksi Anak Babi Lepas Sapih. Majalah Ilmiah Peternakan Vol 14 No 1 Tahun 2011. Phal 33-35.

Bali dalam Angka. 2015. Badan Pusat Statistik Provinsi Bali. Penerbit BPS Provinsi Bali.

Budaarsa, K., A. W. Puger dan I M. Suasta. 2016. Eksflorasi komposisi pakan babi tradisional babi bali. Majalah Ilmiah Peternakan.19.1: 6-11.

Correa, E. K. 2000. Environmental condition and performance in growing and finishing swine raised under different types of litter. Brazilian Journal of Animal Science. v.29, p.2072-2079,

Correa, E. K., I. Bianchi, R. da R. Ulguim, M. N. Correa, C. C. Turnes, and T. L. Junior. 2009. Effect of different litter depthon environmental parameters and growth performance of growing finishing pigs. Ciencia Rural Vol 37 No 838-843 May-June.

Floresa. 2014. Begini Cara Buat Kandang Babi Sederhana, Tapi Bebas Bau dan Lalat.http://www.floresa.co/2014/11/o4/begini-cara-buat-kandang-babi sederhana-tapi-bebas-bau-dan-lalat/. Diakses 20 Desember 2016.

Steel, R. G. D dan J. H. Torrie. 1991. Prinsip dan Prosedur Statistika. Suatu pendekatan biometric. Terjemahan. Penerbit PT Gramedia Pustaka Utama Jakarta. 